\title{
37- Anadolu sahasındaki bazı mutasavvıf şairlerin vezne bakışı ve şiirlerindeki vezin problemleri
}

\section{Salih YILMAZ}

APA: Yılmaz, S. (2021). Anadolu sahasındaki bazı mutasavvıf şairlerin vezne bakışı ve şiirlerindeki vezin problemleri. RumeliDE Dil ve Edebiyat Araştırmaları Dergisi, (25), 620-636. DOI: $10.29000 /$ rumelide.1032444.

Öz

Halk ve divan şiirinden izler taşıyan ancak her iki gelenekten ayrılan yönleri olan tasavvufî şiirin doğru bir şekilde incelenip değerlendirilmesi için mutasavvıf şairin şiire bakışının doğru anlaşılmasına ihtiyaç vardır. Keza vezin açısından başarısız ya da kusurlu görülen tasavvufî şiire de bu bilgiyle yaklaşmak daha sağlıklı değerlendirme yapmaya yardımcı olacaktır. Bu makalede sûfî şairin şiire bakışı ile ilgili yapılan çalışmalardan, divanların inceleme bölümlerindeki vezinle ilgili verilerden ve şiir örneklerinden hareketle şiirlerinde vezin meselesine nasıl baktığına dair ve tasavvufî şiirde veznin nasıl kullanıldığı hakkında tespitlere yer verilecektir. Çalışmada tasavvufi şiir geleneği, sûfî şairin şiire bakışı ve tasavvufî şiirde vezin konuları hakkında genel değerlendirmelerden sonra tasavvufî şiirin 13. yy.'dan günümüze uzanan serüveninde Yûnus Emre, Kaygusuz Abdal, Kemal Ümmî, Şemseddîn-i Sivâsî, Niyâzî-i Mısrî, İsmail Hakkı Bursevî, İbrahim Hakkı Erzurumî, Osman Kemâlî Efendi, Muhammed Lutfî Efendi gibi her asrın temayüz etmiş şairlerinin şiirlerinde tercih ettikleri vezin türü ve vezin kusurları incelenmiştir. Sanat gayesi taşımadan hakikati dile getirmeye çalışan sûfî şair, vezin konusunda genel olarak çok özenli değildir. Bununla birlikte İbrahim Hakkı, Osman Kemâlî Efendi gibi bazı sûfî şairler, vezin konusunda, sanat endişesiyle şiir yazan klasik edebiyatımızın şairleri gibi hassas ve itinalı davranmışlardır.

Anahtar kelimeler: Vezin, tasavvufi şiir, sûfî şair

\section{The meter view of some sufi poets in the Anatolian field and the meter problems in their poems}

\begin{abstract}
In order for Sufi poetry, which has traces of both divan poetry and folk poetry but which is separated from both traditions, to be examined and assessed more accurately, there is a need for correct understanding of Sufi poet's perspective towards poem. Likewise, approaching Sufi poetry, which is seen as unsuccessful or defective in terms of prosody, with this information will help to make a healthier assessment. In this article, the issue will be examined with reference to the studies about Sufi poet's perspective towards the poetry and the data which is in Divan's analysis sections and also the poetry samples. In the light of this information, some certain fixings about how the Sufi poets viewed the prosody in their poems and how they used the prosody in Sufi poetry will be given. In this study, general evaluations were made about the tradition of Sufi poetry, the view of the Sufi poet to poetry and the subjects of prosody in Sufi poetry. Then, in the poems of the important poets such as Yunus Emre, Kaygusuz Abdal, Kemal Ümmî, Şemseddîn-i Sivâsî, Niyâzî-i Mısrî, İsmail Hakkı Bursevî, İbrahim Hakkı Erzurumî, Osman Kemâlî Efendi, Muhammed Lutfi Efendi, the types and
\end{abstract}

Doktora, Bursa Uludağ Üniversitesi, Sosyal Bilimler Enstitüsü, İslam Tarihi ve Sanatları ABD, Türk İslam Edebiyatı Bilim Dalı (Bursa, Türkiye), salih.yilmaz@yalova.edu.tr, ORCID ID: 00oo-0001-6639-686X [Araştırma makalesi, Makale kayıt tarihi: 14.09.2021-kabul tarihi: 20.12.2021; DOI: 10.29000/rumelide.xxxx]

Adres $\mid$ Address

RumeliDE Dil ve Edebiyat Araşturmalar Dergisi $\quad$ RumeliDE Journal of Language and Literature Studies

Osmanağa Mahallesi, Mürver Çiçeği Sokak, No:14/8 $\quad$ Osmanağa Mahallesi, Mürver Çiçeği Sokak, No:14/8

Kadıköy - ISTANBUL / TÜRKIYE 34714 Kadıköy - ISTANBUL / TURKEY 34714

e-posta: editor@rumelide.com e-mail: editor@rumelide.com,

tel: +90 505 7958124, +90 2167730616 phone: +90 505 7958124, +90 2167730616 
errors of prosody of the Sufi poetry from the 13th century to the present day were investigated. Sufi poets, who do not aim for art and try to express the truth, are generally not very attentive to prosody. However, some Sufi poets such as İbrahim Hakkı and Osman Kemâlî Efendi acted as sensitive and meticulously as the poets of our classical literature, who wrote poetry with concern for art.

Keywords: Prosody, sufi poetry, sufi poet

\section{Giriş}

Tassavuf edebiyatı; "tekke edebiyatı", "dinî-tasavvufî halk edebiyatı” gibi isimlendirmelerle bazen halk edebiyatı kapsamında bazen de İslami Dönem Türk Edebiyatı başlığı altında divan edebiyatı ve halk edebiyatının dışında müstakil bir edebiyat geleneği olarak ele alınmıştır. Tasnif konusundaki kafa karışıklığında tasavvufî şiirin hem divan şiirinden hem de halk şiirinden izler taşımasının ancak her iki gelenekten ayrılan yönlerinin olmasının elbette ki etkisi vardır.

Şekil bakımından halk ve divan şiiri arasında serbest davranan sûfî şairin şiirindeki şekle dair özellikleri isimlendirmek günümüz edebiyat araştırmacılarında farklı yorumların ortaya çıkmasına sebep olmuştur. Dört mısralık birimler hâlinde yazılmış bir şiir, şekle ait diğer hususiyetlere bakılarak semai ya da musammat olarak adlandırılabilir. Bu ayırımda bakılacak özelliklerden biri de vezindir. Yine beyit nazım birimiyle, aruz vezniyle, aa ba ca kafiye düzeniyle söylenmiş 5-15 beyitlik manzumeler gazel olarak adlandırılmakta ancak tasavvufî şiirde hece ile yazılmış gazellere de rastlanabilmektedir. Eğer bu durum fark edilmezse şiirlerin vezin tespitinde hata yapılabilmektedir.

Çalışmanın ilk bölümünde tasavvufî şiir geleneği, sûfî şairin şiire bakışı ve tasavvufî şiirde vezin konu başlıkları üzerinden bir sûfî için şiirin ne anlam ifade ettiği irdelenecektir.

İkinci bölümde Anadolu sahasında 13. yy. - 20.yy. arasında tasavvufî şiirde temayüz etmiş şairlerden seçtiğimiz on bir şairin divan veya divançelerindeki şiirlerden hareketle tasavvufî şiirdeki vezin meselesi örnekler üzerinden incelenecektir. Vezin kusurlarının metinde vurgulanmasıyla ilgili farklı uygulamalar ve öneriler (Köksal, 2009: 63-86) olmakla birlikte seçilen şiir metinlerindeki vezin kusurlarının; imaleli hecelerin altı çizilerek, zihaflı heceler koyu yazılarak, medli hecelere ilişkin kusurlar dipnotta belirtilerek, metin tamiri maksadıyla yapılan eklemeler ise köşeli parantez içerisine alınarak gösterilmesi tercih edilmiştir.

Sûfî kimliği bilinen ancak sanat yönü ön planda olan ve bu yüzden klasik edebiyat kapsamında değerlendirilen Fuzûlî, Şeyh Gâlib gibi şairler ve Türk dilinde şiir söylememiş şairler değerlendirme dışında tutulmuş̧tur.

Sûfî şairin poetikası ile ilgili yapılmış çalışmalar² olmakla birlikte, sûfî şairin vezin meselesiyle ilgili müstakil bir çalışmaya rastlanmamıştır. Çalışmanın bu alandaki eksikliği gidermeye katkısı olacağı düşünülmektedir.

\section{Tasavvufî şiir geleneği ve sûfî şairlerin şiire bakışı}

Ahmet Yesevî ile başlayan tasavvufi şiir geleneği Anadolu'ya yayıldığında, daha ilk zamanlarda, geleneğin en güçlü sesi Yunus Emre ile geniş halk kitlelerine ulaşmıştır. Bu şiir geleneğinin Anadolu'da

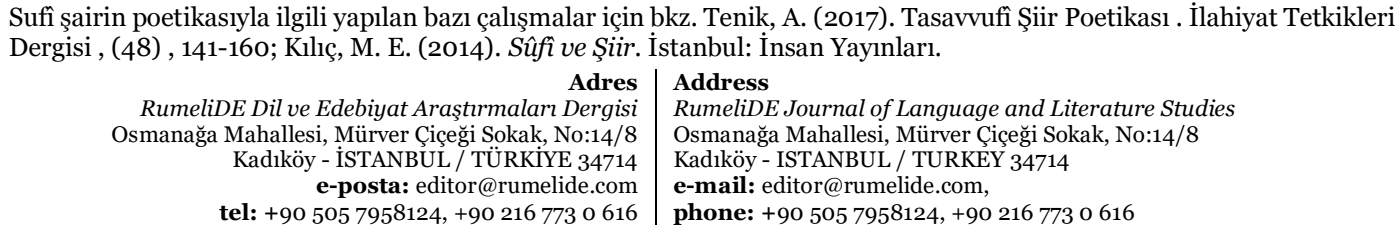


asırlar boyu etkisini sürdürmesi ve nice sûfî şair yetiştirmesinde tasavvufi şiirin halk zevkiyle uyumlu olmasının elbette ki etkisi vardır (Ceylan, 2010: 42).

Tasavvufî şiir; nazım şekli, nazım türü, nazım birimi, vezin gibi hususiyetler bakımından halk şiiri ve divan şiiri ile ortak kullanımlara sahiptir. Sûfî şair bir yandan aruz vezniyle mesnevi, kaside ve gazel formuyla şiirler yazarken diğer yandan da hece ölçüsüyle koşma, mani gibi formlarda şiirler yazmıştır. Ancak her iki şekilde de aynı muhtevayı dile getirmişlerdir. Bu muhtevaya bağlı olarak tasavvufî şiire özgü tevhit, münacat, na't, mevlit, miraciye gibi türler ortaya çıkmıştır. Sûfî şair şekil ve şiir tekniğine ait unsurların peşinde değil, samimiyetin peşindedir. Cezbe halinde söylenmiş şiirlerde vezin aksaklıkları, kelime tekrarları görülebilir (Ceylan, 2010: 43). Sûfî şairler zaman içerisinde divan şiirinden etkilenmiş olsalar da yerlilik ve samimiyet konusunda divan şairlerinden; halk şiirinden etkilenmiş olsa da fikri-felsefi derinlik bakımından halk şairlerinden daha üst bir konumda olmuşlardır (Ceylan, 2010: 42). Divan şiirindeki teslimiyet ve halk şiirindeki mağduriyet yerini tasavvufi şiirde dengeli bir tevekküle bırakmıştır (Ceylan, 2010: 44).

Sûfî şairlerin aynı dönem ve coğrafyadaki diğer sanatkârlardan ayrılan bir yönü de tasannu yapmak ya da bediî ihtiyaçları karşılamaktan ziyade tasavvufu anlatmak, öğretmek maksadıyla şiir yazmalarıdır (Ceylan, 2010: 43). Bu amaç doğrultusunda kullandıkları dil de halkın ekserisi tarafından anlaşılabilecek bir dildir. Vezni seçerken de kimi zaman aruzu, kimi zaman heceyi, kimi zaman aruza yakın heceyi (ya da heceye yakın aruzu) tercih etmişlerdir. Hasılı sûfî şair için nasıl söylendiği değil ne söylendiği önemlidir.

Tekke şiiri olarak da adlandırılan tasavvufi şiir, tasavvuf ilminin tedris edildiği tekkelerde yazılan şiir değildir. Aynı şekilde şiir, tekkenin bir faaliyet konusu da değildir (Kemikli, 2007: 179). Bu şiirin dünyasını anlayabilmek için sûfî şairin şiirlerine verdikleri isimlendirmelere bakmakta fayda var: Ahmet Yesevî ve takipçileri şiir yerine "hikmet" demeyi tercih etmişlerdir. Daha sonraları Anadolu'da nutuk, nefes, sunuhât gibi tabirler kullanılmıştır (Kemikli, 2007: 180). Bu şiiri, Abdulhak Hamid "şi’r-i hakikî", Yahya Kemal "ledünnî şiir”, Bilal Kemikli “irfânî şiir” olarak adlandırmışlardır (Kemikli, 2007: 180). Bu isimlendirmelerin tamamı, bu şiir türünde mananın şeklin önünde olduğunu göstermektedir. "Ledünnî" ve "irfânî" kavramları tasavvufî şiirin ilham kaynağı hakkında da fikir vermektedir. İlm-i ledün, ilâhî bir lütuf ile müşahede ve murakabe yoluyla kalpte ortaya çıkan bir ilimdir. Sûfî şair için kalp, sözlerin annesidir. Dolayısıyla sûfî şair, şiirini ilâhî ilhamlarla inşa etmektedir. Sanat kabiliyeti de sanatkâra doğuştan verilmiştir (Kemikli, 2003: 88-89).

İrânî şiir olarak da anılan tasavvufi şiir, gayesi ve fikri olan bir şiir türüdür. Bu şiirde ya bir temel değer ele alınıp irdelenir yahut bir tecrübe ile geriden gelenlere rehber bir metin oluşturulur. Temel gaye hakikattir. İdrake ulaşan şair, bu idrak seviyesiyle konuşur ve muhatabına hakikatin bilgisini verir. İrfânî şiir, seyr ü sülûk sürecinde gidilen yolu tasvir eden ifadeleri, uğranan duraklarda tadılan zevkleri, tecellileri anlatmaktadır. Dolayısıyla irfânî şiir, manevi anlamda terakki etmiş ve kemale ermiş insanların şiiridir.

Oğlanlar Şeyhi İbrahim Efendi’nin Vahdet-nâme'sinde fikrin sanat kaygısının önüne geçmesiyle ilgili şu hadise anlatılır: "Bir gün şiirden anlayan, şiir zevkine ermiş ve bu meydanda söz söyleyebilecek yetkinlikte bir "sühanver", ünlü mutasavvıf ve şair Mevlânâ'ya, sûfî şairlerin kafiye ve vezne riayet etmek yerine manayı öne çıkarmalarının hikmetini sorar. Bu soruyu Mevlânâ, sûfî şairin içinde bulunduğu manevi hâl ile izah etmeye çalışır. Buna göre herhangi bir sûfî şair, bir şiir terennüm ederken, "Cemâl-i Yâri” gözlediğinden mest olur. İşte bu mestlik hâlinde bulunan sûfî harfsiz bir avaz işitir. Onun şiir

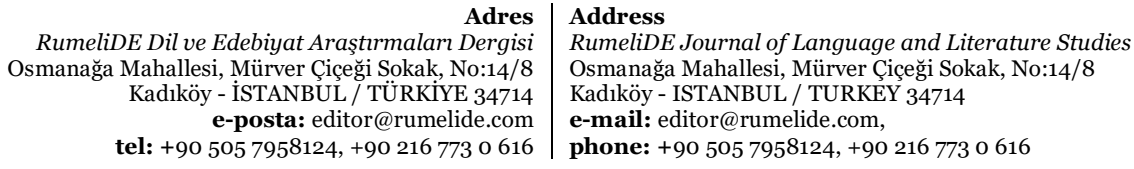


yazarken yaptığı, bu âvâzı terennüm etme gayretinden başka bir şey değildir. Bunun için onlar, kafiye ve vezinle mukayyed değillerdir (Kemikli, 2003: 87).”

Şiirde tasannu gayreti ne kadar öne çlkarsa ve şiir ne kadar mazmunlarla örülürse gerçek mecrasını o ölçüde kaybedecektir. Tasavvuf şiirinde önemli olan ise söyleyiş biçiminden ziyade söylenendir (Tenik, 2017: 148).

Sûfî şairler için şiir "tecellî-i ilâhî"dir. Bu sebeple şairlik iddiasında ve çabasında değildirler. Şairlik vasfını teberrüken ya da tenezzülen taşıyan bu kişilerin şiirleri ele alınırken şairliği meslek edinmiş kişilerin şiirlerindeki estetik ve şekil hassasiyeti aranmamalıdır. Klasik şiirdeki nazım şekilleri ile ilgili kurallar konusunda da sûfî şair kalıpların dışına çıkabilir (Ünal, 2014: 237). Sûfî şair divan şiirinde görülen edebî taassuba ve mükemmeliyetçiliğe sahip değildir (Ceylan, 2010: 50). Sûfî şairin sentezci yönünün olduğu, hem halk şiirinin hem de klasik şiirin estetik dünyasına vakıf ama her ikisine de dışarıdan bakan bir anlayışla eser verdikleri unutulmamalıdır.

İhsan Fazlıŏlu'nun ifadesiyle "Şiirin muhatap olduğu varlık, nehir gibi olan varlıktır. Böyle bir varlık, kendisini önceden belirlenmiş bir dile dönüştürmeye çalışan kişiyi muhatap alıp konuşmaz. Esasen verili bir dil üzerinden konuşan kişi, kişi bile değildir; şairse hiç. Çünkü şiir varlıkla muhatap olurken ondan sadece ölçülebilir olanı almaz, onda sadece ölçülebilir olanı görmez. En az onun kadar Varlık’ta ölçülemez olanı da dikkate alır, göz önünde bulundurur. Şiir sınırlandırmaz, belirlemez, tanımlamaz kısaca had koymaz. Çünkü şiir akıcı olanın biteviye avlanamayacağının farkındadır. Zaten akıcı olan bi’ttab ölçülemez olanı içerir. Ölçülemez olanı ise doğası gereği sınıra karşı direnir. Bütün bir varlığı ölçülmez kılmaya çabalar (Fazlığlu, 2001: 4-6).”

Tasavvufi şiirde şekil unsuru ikinci planda kalmışsa da bazı sûfî şairler şiir tekniği bakımından başarılı olmuşlar ve güzel örnekler verebilmişlerdir. Sadece estetik yönden bakıldığında dahi kudretli mutasavvif şairler vardır. Divanındaki bütün şiirleri dinî-tasavvufi muhtevaya sahip olan Erzurumlu İbrahim Hakkı gibi sûfî şairler aynı zamanda sağlam bir şiir tekniğine sahip ve aruz veznini kullanmakta da gayet başarılı görülebilmiştir (Kılıç, 2014: 128-129).

\section{Tasavvufî şiirde vezin}

Hem halk edebiyatından hem de divan edebiyatından izler taşıması tasavvufi şiirde dikkat çeken hususlardan biridir. Şairler, halk şiirinin nazım şekillerinde ve nazım türlerinde hece veznini kullanırken divan şiiri nazım şekillerinde ve nazım türlerinde aruz veznini tercih etmişlerdir. Ahmet Yesevî, Yûnus Emre, Kaygusuz Abdal, Hacı Bayrâm-ı Veli, Ümmi Sinan, Niyâzî-i Mısrî gibi tasavvufi şiirin önde gelen şairleri hece ölçüsünü kullanmakla birlikte aruz ölçüsüne de hâkimdirler. Bununla birlikte aruzla yazılan şiirler heceyle yazılan şiirlere göre sayıca daha fazladır. Bunda hitap ettikleri kitlenin edebî zevkine uygun söz söyleme amacının olduğunu söylemek mümkündür (Özsoy, 2011: 578). Diğer bir sebep ise tasavvufî şiirin İslam öncesi Türk edebiyatına millı̂ edebiyat özelliği kazandıran millî üslup ve karakteri yok etmeyip onu İslam dininin esaslarıyla ve ruhuyla yeniden işleyerek zenginleştirmiş olmasıdır (Kemikli, 2018: 17). Kafiyenin ya da veznin kusursuz olması sûfî şairin olmazsa olmazı değildir (Kılıç, 2014: 129). Bilhassa iktibas yapıldığında ya da Arapça bir ibare şiirde yer aldığında vezin feda edilebilir.

Üzerinde durulması gereken diğer bir husus da özelde aruzun, genel anlamda şiirin şekle ait hususiyetlerinin şairin hareket alanını ne kadar kısıtladığı meselesidir. Şiirdeki kelimelerin belli hesap dâhilinde ölçülendirilmesi ahenk bakımından olumlu bir tesir bıraksa da vezin ya kafiye kaygısıyla

\footnotetext{
Adres Address

RumeliDE Dil ve Edebiyat Araştırmaları Dergisi $\quad$ RumeliDE Journal of Language and Literature Studies Osmanağa Mahallesi, Mürver Çiçeği Sokak, No:14/8 $\quad$ Osmanağa Mahallesi, Mürver Çiçeği Sokak, No:14/8 Kadıköy - ISTANBUL / TURKIYE 34714 Kadıköy - ISTANBUL / TURKEY 34714 e-posta: editor@rumelide.com e-mail: editor@rumelide.com, tel: +90 505 7958124, +90 2167730616 phone: +90 505 7958124, +90 2167730616
} 
manaya uygun düşen bir kelimenin kullanılamaması anlamı olumsuz yönde etkileyecektir. Hiçbir konu onun için aşktan daha mühim değildir (Ayvazoğlu, 1993: 168). Ruh açısından bedene hapsolmuşluktan daralan sûfî şairler bazen şekle ait unsurların sınırlarından azade olmak istemiş olabilirler. Mevlânâ’nın şu sözleri bu ruh hâlini yansıtmaktadır:

Ben kafiye düşünüyorum oysa sevgilim bana

Vechimden başka bir şey düşünme diyor

Diyor ki ey benim kafiye düşünenim rahat ol

Benim yanımda en güzel kafiye sensin

Harf ne oluyor ki sen onu düşünesin

Nedir ki harf, üzüm bağının çitten duvarı

Harfi, sesi, sözü artık birbirine vurup parçalayalım da

Seninle bu üçü olmaksızın konuşayım, ah (Kılıç, 2014:129)

Şeklin bağlayıcılığı konusunda kendini azade hisseden sûfî şairlerin de bu ruh hâline uygun davrandıkları, lüzumuna göre aruz ve heceden birini tercih ettikleri, aruzla yazılan şiirlerde çokça imale ve zihaf yaptıkları hatta bazen bu iki vezni aynı şiirde kullandıkları görülmektedir.

Her ne kadar sûfî şair için kalıplar ya da ölçüler bağlayıcı bir unsur değilse de tamamen ihmal edilmemiştir. Çünkü ölçü bir ahenk unsurudur ve güfteden besteye geçişte önemli bir rol oynar (Kılıç, 2014: 131). Yahya Kemal'in ifadesiyle şiir bir "dil musikîsi”dir. Eğer bu müzikalite olmazsa şiir düzyazıdan farklı olmaz (Beyatl, 1971: 52-53). "Şair, aruzun tef'ileleriyle varlığın temelindeki ritmi, değişen şeylerin ardındaki değişmeyen ahengi aramaktadır (Ayvazoğlu, 1993:168).” Nitekim klasik Türk müziği formları içinde bestelenmiş şiirlere bakıldığında şiirlerin vezinleri ile bunların bestelenmesinde kullanılmış musikî usulleri arasında dikkat çekici bir ilişki görülmektedir (Tanrıkorur, 1995: 373). Burada zikredilmesi gereken diğer bir husus ise tekkelerin Şeyhülislam Esad Efendi'nin ifadesiyle "şiir ve musikînin yegâne mercii” olmasıdır (Behar, 1998: 47-50). Dolayısıyla tasavvufî şiirde ahenk ve ritim unsuru olarak veznin belli bir fonksiyonu bulunmaktadır.

Tasavvuf-şiir-musiki ilişkisine rağmen sûfî şair için vezne, kafiyeye ve kelimelerin güzelliğine takılma tehlikesinde olduğu gibi ahenge ya da ritme takılmak da bir tehlikedir. Zira Allah'ın vechinden başkası perdedir. Madde, cisim, beden gibi kafiye, kelime ve vezin de mahlûktur ve onlara takılmamak gerekir (Kılıç, 2014: 142).

Bu bilgiler ışığında mutasavvıf bir şair için vezin meselesinin öncelikli bir mesele olmayıp yakın döneme ait bir tartışma konusu olduğunu söylemek mümkündür.

\section{Sûfî şairlerin divanlarında vezin}

$\mathrm{Bu}$ bölümde 13-20. sûfî şairleri hakkında genel bir değerlendirme yapabilmek için Yûnus Emre, Kaygusuz Abdal, Kemal Ümmî, Usûlî, Şemseddîn-i Sivâsî, Sun’ullah Gaybî, Niyâzî-i Mısrî, İsmail Hakkı Bursevî, Erzurumlu İbrahim Hakkı, Osman Kemali, Muhammed Lutfî Efendi gibi yaşadıkları asırda öne çıkmış divan veya divançe sahibi sûfî şairlerin şiirleri vezin yönünden incelenmiştir.

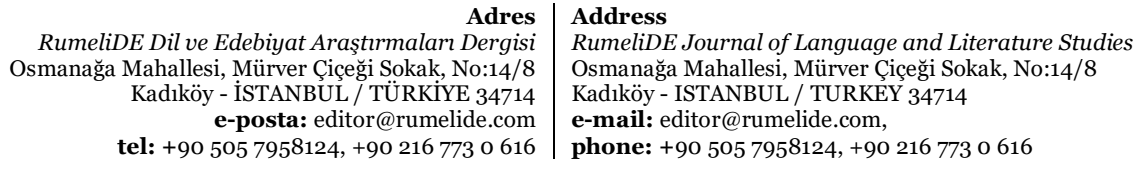




\title{
Yûnus Emre Dîvân'da vezin
}

Yûnus Emre (ö. h. 720/m. 1320-1321)3 tasavvufî şiir geleneğinin Anadolu'daki ilk ve güçlü isimlerinden biridir ve kendisinden sonra gelen mutasavvıf şairleri şiirleriyle önemli ölçüde etkilemiştir. Yûnus Emre Dîvânı'nda hem hece hem de aruz vezniyle yazılmışs şiirler olmakla birlikte hece ölçüsüyle yazılmış şiirler sayıca daha çoktur. Aruzla yazılmış şiirlerde ise önemli hatalar yapılmıştır. Dönemi dikkate alındığında bu durum elbette ki tabiîdir. Yûnus'un aruzla yazdığı şiirlerin dikkati çeken bir diğer özelliği ise hece veznine en çok uyan basit cüzlerle yazılmış olmasıdır (Tatcı, 1990: 54, 55). Musammat olarak yazılmaya müsait olan ve dörtlükler hâlinde yazıldığında 8'li hece ölçüsüne de uygun olan Müstefilün/ Müstefilün/ Müstef'ilün/ Müstefilün vezni Yûnus'un en çok tercih ettiği aruz veznidir. 11'li hece ölçüsüne uyan Mefâ'̂llün/ Mefâ’îlün/ Fe'ûlün, Fâ'ilâtün/ Fâ'ilâtün/ Fâ'ilün; dörtlükler hâlinde 8'li hece ölçüsüyle yazılmış şiirle uyumlu Mefâ'îlün/ Mefầ̂llün/ Mefâ’̂̉lün/ Mefâ’îlün, dörtlükler hâlinde 7’li hece ölçüsüyle yazılmış şiirle uyumlu Mef'ûlü/ Mefầ̂̂lün/ Mef'ûlü/ Mefâ’̂̂lün vezinleri ve 14'lü hece ölçüsüne uyan Fe'ilâtün/ Fe'ilâtün/ Fe'ilâtün/ Fe'ilün vezninin Fa'lün'le biten versiyonu Yûnus'un tercih ettiği aruz vezinlerindendir. Aruz ve hecenin bu kadar iç içe geçmesi ve aruz veznindeki hatalar zaman zaman şiirin vezninin aruz mu yoksa hece mi olduğu konusunda tereddütün doğmasına hatta bazen yanlış kanaatler oluşmasına sebep olmaktadır.

\author{
Fe’ilâtün Fe’ilâtün Fe’ilâtün Fe’ilün / 7+7=14'lü hece ölçüsü \\ Derviş olan kişiler deli olagan olur \\ Aşk neydigin bilmeyen ana gülegen olur
}

Gülme sakın sen ana iyi degildir $\underline{\text { sana }}$

Kişi neyi güler[i]se başa gelegen olur

Âh4bu aşkın eseri her kime ugrar ịse

Derdine sabretmeyen yolda kalagan olur (Tatc1, 1990: 119)

\section{Kaygusuz Abdal Dîvânı'nda vezin}

Şiirlerinde hem aruzu hem de -fazla tercih etmemekle birlikte- heceyi kullanan Kaygusuz Abdal (ö. h. 845/m. 1444), aruz vezinleri içinde daha çok bahr-i hezec'den Mefầ̂lün/ Mefâ’̂lün/ Fe'ûlün, Mef'ûlü/ Mefâ’ilün/ Fe'ûlün, Mef'ûlü/ Mefâ’̂llü/ Mefầ̂llü/ Fe'ûlün vezinlerini; bahr-i remel'den Fâ’ilâtün/ Fâ’ilâtün/ Fâ’ilâtün/ Fâ’ilün ve Fâ’ilâtün/ Fâ’ilâtün/ Fâ’iün vezinlerini, bahr-i recez'den Müstefilün/ Müstefilün/ Müstefilün/ Müstefilün veznini kullanmayı tercih etmiştir. Bu vezinlerden Mefầ̂lün/ Mefâ’îlün/ Fe'ûlün ve Fâ’ilâtün/ Fẩilâtün/ Fâ'ilün vezinleri 11'li hece ölçüsüyle, Mefôulü/ Mefâ'̂lü/ Mefâ’̂̂lü/ Fe'ûlün vezni 14'lü hece ölçüsüyle, Müstef ilün/ Müstef ilün/ Müstef'ilün/ Müstef'ilün vezni ise dörtlükler hâlinde yazıldığında 8'li hece ölçüsüyle uyumludur.

Kaygusuz Abdal’ın şiirlerinde imale ve zihaf kusurlarına sıkça rastlanmaktadır:

\footnotetext{
3 Hicri ylı miladi yıla çevirirken Türk Tarih Kurumunun Tarih Çevirme Kılavuzu dikkate alınmıştır. https://www.ttk.gov.tr/tarih-cevirme-kilavuzu/ Medli hece, kapalı tek bir hece olarak kullanılmıştır.

Adres Address

RumeliDE Dil ve Edebiyat Araştırmaları Dergisi Osmanağa Mahallesi, Mürver Çiçeği Sokak, No:14/8 Kadıköy - İSTANBUL / TÜRKIYE 34714 e-posta: editor@rumelide.com tel: +90 $5057958124,+902167730616$

RumeliDE Journal of Language and Literature Studies Osmanağa Mahallesi, Mürver Çiçeği Sokak, No:14/8 Kadıköy - ISTANBUL / TURKEY 34714

e-mail: editor@rumelide.com,

phone: +90 5057958124 , +90 2167730616
} 
Müstefilün Müstefilün Müstefilün Müstefilün

Ahmed gibi ârif ola öz hâline vâkıf ola

Sıdk u safâla gönlini tevhîde mekân eyleye (Güzel, 2021: 411)

Mefâ'îlün Mefâ'îlün Fe’ûlün

Hakîkat gevheri bite cânumda

Cevâhir gönlüm içinde cân oldı (Güzel, 2004: 172)

$\cdots$

\section{Kemâl Ümmî Dîvânı'nda vezin}

Kemâl Ümmî (ö. h. 88o/m. 1475-1476), heceden aruza geçiş sürecinin bütün özelliklerini eserlerinde hissettirmesi bakımından önemli bir şairdir (Yavuzer, 2008: 92). Divanındaki 8+8 hece ölçüsüyle yazdığı 135 nolu şiirinin (Yavuzer, 2008: 753) dışındaki bütün şiirlerini aruz vezniyle yazmıştır. Vasfi Mahir Kocatürk’e göre devrindeki diğer şairlere nazaran aruzu kullanmakta mahirdir (Kocatürk, 1970: 282-283). İsmail Ünver ise Kemâl Ümmî’nin aruzda pek de başarılı olmadığı görüşündedir (Ünver, 1987: 24). İsmail Ünver’in bu görüşü, Kemâl Ümmî’nin şiirlerindeki imale ve zihafların -bazen bu şiirlerin heceyle yazılmış olduğunu düşündürecek kadar- fazla olmasından dolayı haklı görünmektedir (Yavuzer, 2008: 92).

\section{Fe'ûlün Fe'ûlün Fe'ûlün Fe'ûl}

Aga kara saçun boyandı aga

Neye döndi şu bâga düşsen aga

Taga urma tag 'adl ile merhem ur

Ki zulm odı yakar düşerse taga

Aga düşme bu yirde giç dâneden

Ki cânun kuşı ụça göge aga

Yaga bala toyur kamu acları

Dilersen ki üstüne rahmet yaga (Yavuzer, 2008: 93)

$\cdots$

Vezinde zihaf yapmak kelimenin aslını ve alışılmış ahengini bozmasıyla kulağa hoş gelmediği için imaleye göre daha büyük bir yanlışlık sayılmıştır (İpekten, 1994: 139). Kemal Ümmînnin şiirlerinde zihaflara sıkça rastlanır. 5 Bunun yanında dünyâ, şâh, zîrâ gibi birçok kelime vezin gereği kasr yapılarak dünye, şeh, zire şeklinde kullanılmıştır (Yavuzer, 2008: 93).

$5 \quad$ Hayati Yavuzer, a.g.e., s. 93'te verilen bu bilginin altında örnek bir mısra bulunmamaktadır. Divan'daki şiirlere bakıldığında da zihaf olarak görülebilecek hecelerin vasl yapılarak açı heceye dönüşebileceği görülmüştür. Dolayısıyla bu bilgi teyide muhtaçtır.

RumeliDE Dil ve Edebiyat Araştırmaları Dergisi Osmanağa Mahallesi, Mürver Çiçeği Sokak, No:14/8 Kadıköy - İSTANBUL / TÜRKIYE 34714 e-posta: editor@rumelide.com tel: +90 505 7958124, +90 2167730616
Address

RumeliDE Journal of Language and Literature Studies Osmanağa Mahallesi, Mürver Çiçeği Sokak, No:14/8

Kadıköy - ISTANBUL / TURKEY 34714

e-mail: editor@rumelide.com,

phone: +90 5057958124, +90 2167730616 
Kemâl Ümmî’nin şiirleri arasında aruzu Türkçe kelimelerle başarılı bir şekilde uyguladığına dair örnekler de vardır:

Mefûlü Mefầîü Mefâ'îlü Fe'ûlün

Âh ol toniçün kim ne yini var ne yakası

Ol dahi ya biz ola ya astâr ölüm var

Âh ol agac at üzre binüp gitmek içün kim

İltüp bizi kabr içre koyarlar [ki] ${ }^{6}$ ölüm var (Yavuzer, 1997: 68)

$\ldots$

Kemâl Ümmî’nin şiirlerinde aruz ölçüsüyle ilgili karşımıza çıkan ilginç örneklerden biri de "imâle-i memdûde" ya da "medd" denilen "Arapça ve Farsça kelimelerde bir uzun heceyi ya da sonu iki sessiz harfle veya hemze ile biten bir heceyi bir uzun bir kısa olmak üzere iki hece olarak okuma (İpekten 1994: 134) özelliğini "yazar" ve "var" gibi Türkçe kelimelerde de uygulamış olmasıdır:

\section{Mefûlü Mefầîü Mefầîü Fe'ûlün}

Yazar humârını içen tevbe şarâbın

Hüşyâr dutar pendi gönül levhine yazar

Yol var durış mürşidile menzile ịirş

Ger varmaz isen saçunı sakalunı yol var (Yavuzer, 2008: 94)

\section{Usûlî Dîvânı'nda vezin}

Usulî (ö. h. 945/m. 1538), şïrlerinde büyük oranda aruz ölçüsünü kullanmış, dokuz şiirini ise hece ölçüsüyle yazmıştır. Aruzla yazılan şiirlerin yarısında remel bahrinin Fâ'ilâtün/ Fâ’ilâtün/ Fâ’ilâtün/ Fâ’ilün kalıbı, diğer şiirlerinde ise 11 farklı aruz kalıbı kullanılmıştır. Usûlî, aruz vezninin Türk şiirine iyice yerleştiği ve başarılı bir şekilde uygulandığı bir dönemde yaşamıştır. Bununla birlikte tasavvufî şiirde görülen aruz kusurlarına, özellikle imaleye, onun şiirlerinde de sıkça rastlanmaktadır (İsen, 1990: 22-23).

\section{Fẩilâtün Fẩilâtün Fâilâtün Fẩilün}

Bir melek sevdim ki görse ins ü cân hayrân olur

Allah Allah ol perî-peyker ne hûb insân olur

Kûşe-i hicrânda ölmüş yatar ịdik derd ile

Sohbetinde rûha erişdik ne hoşça cân olur

Sûzum arz etse kebûter yâra sûzumdan benim

Od saçup minkârdan kaknos gibi biryân olur sehven yazılmamıştır.

Adres
RumeliDE Dil ve Edebiyat Araştırmaları Dergisi Osmanağa Mahallesi, Mürver Çiçeği Sokak, No:14/8 Kadıköy - İSTANBUL / TÜRKIYE 34714 e-posta: editor@rumelide.com tel: +90 $5057958124,+902167730616$
Address

RumeliDE Journal of Language and Literature Studies Osmanağa Mahallesi, Mürver Çiçeği Sokak, No:14/8

Kadıköy - ISTANBUL / TURKEY 34714

e-mail: editor@rumelide.com,

phone: +90 5057958124, +90 2167730616 
Bilmezem keyfiyyet-i aşַ̧ı nice şerh eyleyem

Her kime keşf eylesem esrârımı hayrân olur (İsen, 2020: 168)

\section{Şemseddîn-i Sivâsî Dîvân'nda vezin}

Şemseddîn-i Sivâsî (ö. h. 1006/m. 1597) Dîvânı'ndaki toplam 290 şiirden 278’i aruz vezniyle, 7'si hece ölçüsüyle yazılmıştır. Arta kalan beş şiirin vezni ise ne tam olarak aruza ne de heceye uymaktadır. Bu şiirlerden biri üç beyitten ibarettir. Bu şiirin gazel niyetiyle yazılmaya başlanmış ve yarım kaldığı için vezni tam oturmamış olması ya da manaca yeterli görülüp şekil yönünün göz ardı edilmiş olması muhtemeldir. Nadiren tercih edilen "Fe'ilâtün Fe'ilâtün Fe'ilâtün Fe'ilâtün" vezniyle yazılmaya çalışıldığı anlaşılan bu şiirin iki yerine ekleme yapılarak7 vezne uygun hâle getirilmesi mümkündür:

Fe'ilâtün Fe'ilâtün Fe'ilâtün Fe'ilâtün

Zıll-i tûbâyı bulan sâye-i tarfâyı anar mı

Kadr-i a'lâya iren menzîl-i ednâyı anar mı

Tâli’i yâri idüp sohbet-i cânânı bulan [lar]

Hâr-i harîr8le olan “işret-i rüsvâyı anar mı

Hak ile bâtılı fark itmeyenün 'aklı mı var [dur]

Rabb-i A'lâyı bilen Lât ile Uzzâ'yı anar mı (Süer, 2017: 288)

Sivâsî Dîvânı'nda belli bir vezne uymayan diğer dört şiir ise müstakil beyitlerdir.9 Bunlardan ikisinde Arapça, Farça ibareler bulunmaktadır ki bu durumda veznin feda edilebildiği yukarıda belirtilmişti. Ancak bu beyitlerde ibarenin olmadığı mısralarda da belli bir vezin tespit edilememektedir:

Micmer gibi germ-nefs olsam 'aceb olmaz

Ez-hubbuke kad evkadnî kalbi nârâ (Süer, 2017: 323)

Sivâsî Dîvânı'nda aruzla yazılan şiirlerden 132'si remel, 124'ü hezec, 8’i recez, 7’si hafif, 4'ü muzarî ve 1’i seri’ bahrinde yazılmıştır. Bunlar Türk edebiyatında yaygın olarak kullanılan aruz kalıplarıdır (Süer, 2017: 36).

Heceyle yazılmış yedi şiirden ikisi dörtlükler hâlinde $6+5=11^{\prime} l i$, biri beyitler hâlinde ve gazel formunda $6+5=11^{\prime} l i$, ikisi beyitler hâlinde ve gazel formunda $8+8=16$ 'll, ikisi beyitler hâlinde ve gazel formunda $7+7=14$ 'lü olarak yazılmıştır.

Şemseddîn-i Sivâsînin şiirlerinde imale ve zihaf örneklerine sıkça rastlanılmaktadır:

Fe'ilâtün Mefầilün Fe'ilün

Ez-mutî'an u gümrâh-1 'âlem

Sanadur cümlesinün îmâsı (Süer, 2017: 163)

Eklemeler köşeli parantez içinde belirtilmiştir.

Medli hece, kapalı tek bir hece olarak kullanılmıştır.

Bkz. Fatih Ramazan Süer, Şemseddîn-i Sivâsî Dî̀vânı, 22, 23, 27 ve 30 numaralı şiirler.

Adres Address

RumeliDE Dil ve Edebiyat Araştrmaları Dergisi Osmanağa Mahallesi, Mürver Çiçeği Sokak, No:14/8 Kadıköy - İSTANBUL / TÜRKIYE 34714 e-posta: editor@rumelide.com

RumeliDE Journal of Language and Literature Studies Osmanağa Mahallesi, Mürver Çiçeği Sokak, No:14/8

Kadıköy - ISTANBUL / TURKEY 34714 tel: +90 $5057958124,+902167730616$

e-mail: editor@rumelide.com

phone: +90 505 7958124,+90 2167730616 
Müfte’ilün Müfte’ilün Müfte’ilün Müfte’ilün

Gamlılara virüir safâ cevri gidüp bulur vefâ

Hastalara dârü'ş-şifâ kubbe-i pür-nûr-1 Habîb (Süer, 2017: 173)

$\cdots$

Fẩilâtün Fẩilâtün Fâ'ilâtün Fâ'ilün

Ma'nâ-yı 'ilm-i ledün 'irfân içinde gizlidür

Şüphesüz nûr-ı Hudâ îmân içinde gizlüdür (Süer, 2017: 192)

\section{Sun'ullah Gaybî Dîvan'nda vezin}

Sun’ullah Gaybî (ö. h. 1086/m. 1676'dan sonra ), şiirlerinde hem aruz hem de hece ölçüsünü kullanan bir şairdir. Aruzla yazdığı şiirlerin 66'sı remel, 24'ü hezec, 4'ü recez ve 1’i hafif bahriyle yazılmıștır. Gaybî Divanı’ında ekseriyetle tercih edilen remel ve hezec bahirleri çokça kullanılan bahirlerdir. Bununla birlikte recez bahrinin nadiren tercih edilen "Müstefilün Müstefilün" ile hafif bahrinin Türk şiirinde kullanılan tek kalıbı olan "Fâ’ilâtün Mefầilün Fa'lün" Gaybînin kullandığı aruz kalıpları arasındadır (Kemikli: 2017: 77).

Gaybî’nin şiirlerinde çok sayıda imâle yapılmıştır. Bu kusurlar değil sadece mutasavvıf şairlerde, hemen her şairde görülebilecek düzeydedir (Kemikli: 2017: 78). İmâleye göre daha büyük bir hata sayılan zihaf örneği yok denecek kadar azdır.

Sûret-i tevhîdi kogll ma'ni-i tevhîde ir

Güftü'l-ma'nî huve'llâh an 'Aliyyu'l-Mürtezâ (Kemikli: 2017: 227)

Fâ'ilâtün Fâ'ilâtün Fâ'ilâtün Fâ'ilün

Bu beyitte ikinci mısranın ikinci hecesinde, zihaf var yanılgısına düşmek mümkündür. Bu mısra "Güft el-ma'na hüve'llâh an 'Aliyy'ül-Murtaza” şeklinde okunduğunda ve ilk hecenin medli hece olduğu dikkate alındığında zihafa gerek olmadığı görülecektir.

Gaybî, daha çok ilâhîlerde hece ölçüsünü kullanmıştır. Dîvân'daki şiirlerin 2'si 5'li, 10'u 7'li, 3'ü 8'li, 2'si 10'lu ve 2'si 11'li olmak üzere toplam 29'u hece ölçüsüyle yazılmıştır. Dîvân'daki 6 şiir ise herhangi bir aruz veznine uymadığı için 14'lü hece ölçüsü olarak değerlendirilmiştir (Kemikli: 2017: 227). Burada şairin maksadının aruzla mı yoksa heceyle mi yazmak olduğu kesin olarak tespit edilememektedir. $\mathrm{Bu}$ şiirlerde halk edebiyatındaki $3+4$ veya $4+3$ şeklinde duraklı okumaya müsait olanlar göz önüne alındığında veznin hece olma ihtimali daha yüksek görünmektedir:

Tâc ma'rifet tâcıdur sanma gayrı ola tâc

Taklîd ile tok olan ledünnîden ola âc

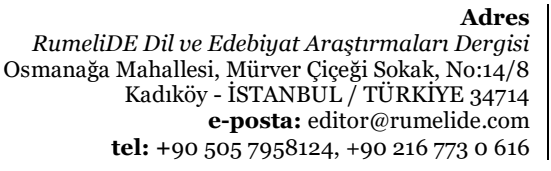

RumeliDE Dil ve Edebiyat Araştırmaları Dergisi Kadıköy - İS tel: +90 505 7958124, +902167730616
Address

RumeliDE Journal of Language and Literature Studies

Osmanağa Mahallesi, Mürver Çiçeği Sokak, No:14/8

Kadıköy - ISTANBUL / TURKEY 34714

e-mail: editor@rumelide.com,

phone: +90 5057958124 , +90 2167730616 
Düşe düş olma sakın düşe aldanup kalma

Hak'dan gayrı ne vardur ta'bire ola muhtâc

Sana ‘âlem görinen hakîkatde Allah'dur

Allah birdür va'llâhi sanma ki ola birkac (Kemikli: 2017: 238)

$\cdots$

Gaybî Dîvânı'ndaki bu şiir yukarıda bahsedilen niteliktedir. Şiiri hece ölçüsü olarak değerlendirdiğimizde ilk dikkatimizi çeken 7+7'lik durakların şiirin tamamında geçerli olmasıdır. Bu durum şiirin 14'lü hece ile yazıldığı kanaatini güçlendirmektedir. Buna ilave olarak ilk beyitte 7 hecelik bölümlerin her birinin içinde 4+3'lük duraklar bulunmaktadır. Bu durum diğer beyitler için düzenli olarak geçerli olmasa da bu beyitte tam olarak geçerlidir. Ĕ̆er bu kanaatimiz doğru ise bu durumda şiirde divan şiirinin nazım birimi ve gazelin kafiye şeması, halk şiirinin ise hece ölçüsü kullanılmıştır ve bu ihtimal kuvvetle muhtemeldir. Bu durumda bu şiir tasavvufi şiirin şekil meselesini çok da önemsemediği ve her iki şiir geleneğini aynı şiirde buluşturabildiğinin bir örneği olmuştur.

\section{Niyâzî-i Mrsrî Dîvân'nda vezin}

Niyâzî-i Mısrî (ö. h. 1105/m. 1694) tespit edilen toplam 231 şiirden 200’ünde aruzu, 31 şiirinde ise hece ölçüsünü kullanmıştır. Mısrî her iki vezni de başarıyla kullanmakla birlikte aruzlu şiirlerinde zaman zaman imale ve zihaf kusurlarına rastlanmaktadır.

\section{Fâ'ilâtün Fâ’ilâtün Fâ'ilâtün Fâ'ilün \\ Ey gönül gel gayrıdan geç aşka eyle iktidâ \\ Zümre-i ehl-i hakîkat anı kılmış iktidâ}

Cümle mevcûdât u ma'lûmâta aşk akdem durur

Zîrâ aşkın evveline bulmadıllar ibtidâ

Hem dahi cümle fenâ buldukda aşk ${ }^{10}$ bâkî kalır

Bu sebebden dediler kim aşka yokdur intihâ

Dilerem senden Hudâyâ eyle tevfîkin refîk

Bir nefes gönlüm senin aşkından etmegil cüdâ (Tatcı, 2015: 346)

\section{İsmail Hakkı Bursevî Dîvânı’nda vezin}

İsmail Hakkı Bursevî (ö. h. 1137/m. 1725), dini tasavvufî pek çok eser vermiş olmakla birlikte edebî yönden en çok emek verdiği eseri dîvânı olmuştur (Yurtsever, 1990: 29). Hece ile yazılmış 11 ilahi

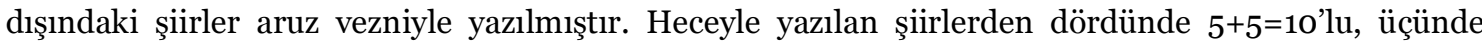
$6+5=11^{\prime} l i$, üçünde $7+7=14^{\prime} l u ̈$, birinde ise 4+5=9'lu ölçü kullanılmıştır.

Bahr-i remelden Fâ’ilâtün/ Fâ’ilâtün/ Fâ’ilâtün/ Fâ'ilün vezni İsmail Hakkı'nın en çok tercih ettiği vezindir. Yine bahr-i remelden Fẩilâtün/ Fầilâtün/ Fâ’ilün, bahr-i hecezden Mefầ'̂lün/ Mefầ̂liün/

10 Medli hece, kapalı tek bir hece olarak kullanılmıştır.

$$
\begin{array}{r}
\text { Adres } \\
\text { RumeliDE Dil ve Edebiyat Araştırmaları Dergisi } \\
\text { Osmanağa Mahallesi, Mürver Çiçeği Sokak, No:14/8 } \\
\text { Kadıköy - İSTANBUL / TÜRKIYE 34714 } \\
\text { e-posta: editor@rumelide.com } \\
\text { tel: +90 505 7958124, +90 } 2167730616
\end{array}
$$

Address

RumeliDE Journal of Language and Literature Studies

Osmanağa Mahallesi, Mürver Çiçeği Sokak, No:14/8

Kadıköy - ISTANBUL / TURKEY 34714

e-mail: editor@rumelide.com,

phone: +90 $5057958124,+902167730616$ 
Mefâ’̂̂lün/ Mefâ̂îlün, Mefâ’̂̂lün/ Mefâ̂̂lün/ Fe'ûlün ve bahr-i müctesten Mefâ’ilün/ Fe’ilâtün/ Mefâ’ilün/ Fe’ilün dîvânda çokça tercih edilmiştir.

Dîvânı’ndaki şiirlere vezin yönünden bakıldığında İsmail Hakkı'nın diğer sûfî şairlere kıyasla daha itinalı olduğu görülmektedir. Bununla birlikte az sayıda da olsa aruz kusurlarına rastlanmaktadır:

Râhat-ı 'ukbâ durur dünyâda zahmetden garaz

'İzzet-i ma’nâ durur sûretde zilletden garaz

Gerçi ef âl-i Hudâ olmaz mu'allel bil-garaz

Ma'rifetdür lîk insânda bu hilkatden garaz

Sûret-i esmâda halk itdi hakîkat âdemi

Ma'nâ-yı Hak anlamakdur işbu sûretden garaz

Lutf u kahrı Hak Ta'âlânun begüm yeksân ${ }^{11}$ dur

Şol muhabbet sirrıdur 'âlemde mihnetden garaz

Nokta-yı fehm eylemekdür bin bir esmâdan murâd

Hakkıyâ vahdet bilinmekdür bu kesretden garaz (Yurtsever, 1990: 353)

Fẩilâtün Fâ’ilâtün Fâ'ilâtün Fâ'ilün

\section{İbrahim Hakkı Erzurumî Dîvânı'nda vezin}

Erzurumlu İbrahim Hakkı (ö. h. 1194/m. 1780) sûfî şairler içerisinde sağlam bir şiir tekniğine sahip ve aruz veznini kullanmakta da gayet başarılı şairlere örnek olarak gösterilmiştir (Kılıç, 2014: 128-129). İlâhînâme adını verdiği divanındaki 399 şiirinden 75’i Mefâ’ilün/ Fe’ilâtün/ Mefâ’ilün/ Fe’ilün, 51'i Fâ'ilâtün/ Fâ’ilâtün/ Fâ’ilâtün/ Fâ'ilün, 34'ü Fe'ilâtün/ Fe'ilâtün/ Fe'ilâtün/ Fe'ilün, 31’i Mefâ’̂̂lün/ Mefâ’̂̂lün/ Mefâ’̂̂lün/ Mefâ’̂̉iun, 3o’u Mefûlü/ Fâ’ilâtü/ Mefâ’̂̂lü/ Fâ’ilün kalıbıyla, diğer şiirleri ise aruzun 19 farklı kalıbıyla yazılmştır (İpekten, 1994: 324). İbrahim Hakkı, diğer sûfî şairlerin tercih ettiklerinden farklı aruz kalıplarını da kullanmıştır.

Aruzu kullanmakta mahir kabul edilen İbrahim Hakkı'nın şïrlerinde aruz kusurları diğer sûfî şairlere nazaran daha azdır:

\section{Fâ’ilâtün Fâilâtün Fâ’ilün}

Uyuma bir kaç gice ey meh-likâ

Tâ sana yüz göstere genc-i bekâ

Dil güneşinden gice çün germ ola

Bu iki çeşmin aça ol tûtiyâ

11 “sân” hecesi nun'la bittiği hâlde bu hece medli hece sayılmıştır.

Adres Address

RumeliDE Dil ve Edebiyat Araştırmaları Dergisi Osmanağa Mahallesi, Mürver Cicceği Sokak, No:14/8 Kadıköy - İSTANBUL / TÜRKIYE 34714 e-posta: editor@rumelide.com
tel: $+905057958124,+90216773$ o 616

RumeliDE Journal of Language and Literature Studies Osmanağa Mahallesi, Mürver Çiçeği Sokak, No:14/8

Kadıöy - ISTANBUL / TURKEY 34714

e-mail: editor@rumelide.com, 616 phone: +90 $5057958124,+90216773$ o 616 
Bir gice sabr eyle yere koyma baş

Murg-1 sa'âdet kona tâ başına

Gündüz olur kesb ü gice 'aşk-1 yâr

Âşık ider her gice zikr-i Hudâ

Halk varup uykuya düşler görür

Bulmuş uyanık kerem-i Kibriyâ (Erzurumî, H.1263: 33)

Erzurumlu İbrahim Hakkı, hece ölçüsüyle yazmayı pek tercih etmemiş olsa da halk şiirine uzak değildir. $\mathrm{O}$, hem heceye hem de aruza uyan cinaslı maniler de yazmıştır. Malum olduğu üzere mani, halk edebiyatında yedili hece ölçüsüyle dörtlük hâlinde yazılan anonim bir nazım şeklidir. Aşă̆ıdaki mani sûfî şairin sentezci yönüne verilebilecek ilginç örneklerden biridir:

Mefûlü Mefầîun

Oldum sana hem-sâye

Sal üstüme hem sâye

Mihrin bana versin fer

Her niçe ki şems aya (İyiyol, 2013: 268)

\section{Osman Kemâlî Efendi Dîvânı'nda vezin}

Hem heceyle hem aruzla şiirler yazan Osman Kemali Efendi (ö. m. 1954), tasavvufî şiirin şekil ve ahenk yönünden başarılı şairlerinden biridir. Osman Kemâlî Efendi’nin şiirlerinde mana güzelliği, derinliği, zenginliği ve samimiyeti kendini hissettiririr. Bilhassa heceyle yazdığı şiirlerinde bir halk ozanının içten sesi duyulur. $6+5=11^{\prime} l i$ hece ölçüsüyle doğduğu köy için söylediği şiirden alınan aşă̆ıdaki dörtlük bu tür şiirlerine örnek olarak verilebilir:

İçinde anamdan doğdum ağladım

Düştüm karanlığa kara bağladım

Kendi ateşimle kendim dağladım

Ey güzeller köyü köyler güzeli (Doğramacı, 1977: 96)

Osman Kemâlî Efendi aruzla yazdığı şiirlerde çok farklı kalıplar kullanmamıştır. Şiirlerinin önemli bir kısmını Fâ’ilâtün/ Fâ’ilâtün/ Fâ’ilâtün/ Fâ'ilün kalıbıyla yazan şairin Mefâ’îlün/ Mefầ̂lün/ Mefầîlün/

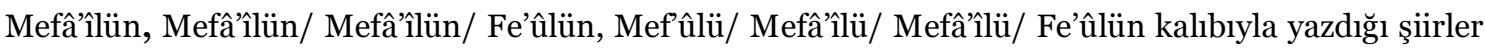
de bulunmaktadır.

Osman Kemâli Efendi'nin şiirlerinde aruz kusurları diğer sûfî şairlerin şiirlerine kıyasla oldukça azdır. Şiirlerinde zihafa rastlamadığımız şairin şiirlerinde imaleye de az rastlanmaktadır. Osman Kemâlî Efendi, medli heceleri kullanmada da diğer sûfî şairlere nazaran daha itinalıdır:

Fe'ilâtün Fe'ilâtün Fe'ilâtün Fe'ilün (Fa'lün)

Sanma her sûret-i insânda olan insândır

Belki hayvânları mahcûb edecek hayvândır (Doğramacı, 1977: 209)

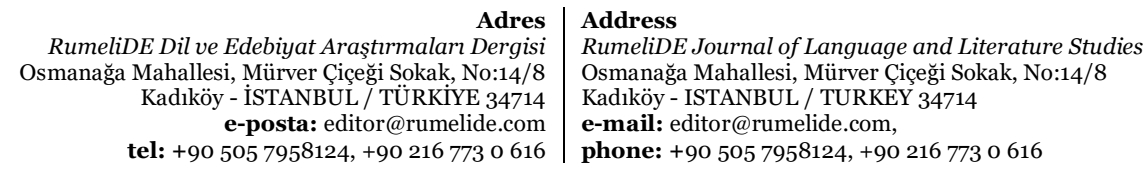




\section{Fâilâtün Fâilâtün Fâilâtün Fẩiün}

Âşkdır her müşkülün miftâhı, fethi, fâtihi

Âşk sergerdanının bil müşkül ü âsânı yok (Doğramacı, 1977: 114)

$\cdots$

Tasavvufî şiirde Arapça ibarelerin bulunduğu beyitlerde aruz kusurları genelde göz ardı edilir. Osman Kemâlî bu ibareleri de aruz kalıbına uygun olarak kullanmıştır:

Gâh melek, gâhî felek, gâhî tabîatde dedim

“Lâ-uhibbü’l-âfilîn” fânîye rağbet kalmadı (Doğramacı, 1977: 102)

...

Fẩilâtün Fâ’ilâtün Fâ’ilâtün Fâ’ilün

\section{Muhammed Lutfî Efendi (Alvarlı Efe)'nin Dîvânçesi'nde vezin}

Muhammed Lutfî Efendi (ö. m. 1956) şiirlerinde aruzun farklı kalıplarını ve hecenin farklı ölçülerini kullanmıştır. Divançesindeki toplam 726 şiirin 183 'ü heceyle geri kalanı aruz vezniyle yazılmıştır. Bu şiirlerin 123'ünde 11'li, 32'sinde 8'li, 10’unda 7'li, 7'sinde 10'lu, 7'sinde 14'lü, 3'ünde 5'li ve 1’inde 16'lı hece ölçüsü tercih edilmiştir.

Aruz vezniyle yazılan şiirlerde 20 ayrı aruz vezni kullanılmıştır. Divançede 191 şiirin kalıbı olan Fâ’ilâtün / Fâ'ilâtün / Fâ’ilâtün / Fâ'ilün en çok tercih edilen aruz kalıbıdır. 121 şiirde Mefâ’̂̂lün / Mefâ’̂̂lün / Mefầ̂̂lün / Mefầ̂̂lün, 108 şiirde Mef'ûlü / Mefầ̂̂lü / Mefầ̂̂lü / Fe'ûlün, ve 31 şiirde kullanılan Müstefilün / Müstefilün / Müstefilün / Müstefilün kalıbı da çokça tercih edilen kalıplardır (Farsakoğlu, 2010: 29-41).

Bu vezinlerden Mefâ̂̂llün/ Mefâ’̂̂lün/ Mefâ’̂lün/ Mefâ’̂̂lün ve Müstef'ilün/ Müstefilün/ Müstefilün/ Müstef'ilün gibi vezinler, iki eşit parçaya bölünebilen, bu hâliyle 8'li hece ölçüsüyle uyumlu ve dörtlük olarak yazmaya müsait vezinlerdir. Bu durum şiirde iki vezin arasında geçişkenliği de mümkün kılmaktadır. Özellikle vezinle ilgili kusurların çokluğu bazen şiirin vezninin hece mi yoksa aruz mu olduğu konusunda da farklı yorumlara sebep olabilmektedir. Muhammed Lutfî Efendi’nin divançesinde buna benzer durumlarla karşllaşabiliyoruz. Divançe'nin Hulâsatü'l-Hakâyık adlı matbu nüshasında Müstefilün/ Müstefilün kalıbında yazılmış gösterilen 24 numaralı manzume bu kalıba göre çok sayıda aruz kusuru taşımaktadır:

Büzr-i muhabbeti eke

Emtâr-ı hikmeti döke

Burc-i dilden șafak söke

Güneş gibi berrâk ola (Lütfi, 2006: 105)

Tasavvufî şiirde çokça rastlayabileceğimiz bu tür şiirleri zorlamayla aruz vezninde yazılmış olarak ele almak yerine hece ölçüsüyle yazılmış olarak değerlendirmek daha doğru bir yaklaşım olabilir.

Muhammed Lutfî Efendi'nin Divançe'sinde vezin konusunda çok itinalı davranılmamış ve şiirlerde imâle ve zihaf türünden pek çok aruz kusuru yapılmıştır:

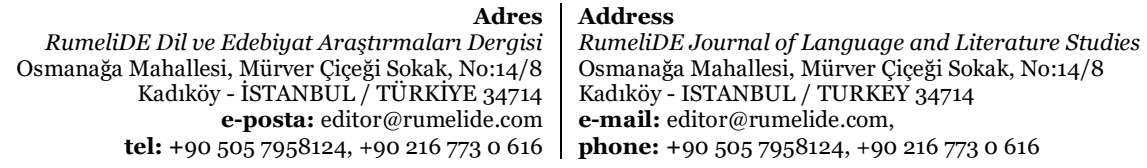




\section{Mefầîun Mefầiün Mefầîlün Mefầîün}

Hakîkat bahrinin gavvâsı ol terk-i mecâz eyle

Çıkar ha alma mazlûmun âhın sen ihtirâz eyle

Çekil semt-i Habîb’e ey gönül azm-i hicâz eyle

Yüzün dut hâk-i pâyine hemân arz-ı niyâz eyle (Lütfi, 2006: 510)

\section{Sonuç}

Sûfî şairler şiirlerinde hem hece ölçüsünü hem de aruz ölçüsünü kullanmışlardır. Tasavvufî şiirin Anadolu'daki ilk ürünlerinin verildiği 13. yy.'da Yûnus Emre Dîvâni'nda heceyle yazılan şiirlere nisbetle aruzla yazılan şiirlerin sayısı daha az iken 14. yy.'da Kaygusuz Abdal'la birlikte aruzla yazılan şiirler heceyle yazılanları sayıca geçmiştir. 13 ve 14. yy. aruzun emekleme dönemidir. Dolayısıyla bu dönemde aruzla yazılan şiirlerdeki kusurlar oldukça fazladır. 15. yy.'dan itibaren aruz vezni yerleşmeye ve şiirde başarılı bir şekilde uygulanmaya başlamıştır. Bununla birlikte sûfî şairin şiire bakış açısına bağlı olarak bazı şairlerce mana derinliği esas alınarak aruzda çok itinalı davranılmamıştır. Bazı dîvânlarda heceyle mi yoksa aruzla mı yazıldığı anlaşılamayan şiirlere de rastlanılmaktadır. Bazen aynı şairin bir şiirinde vezin başarıyla uygulanırken diğer bir şiiri bu yönden zayıf kalabilmiştir. Sûfî şairler, dîvânlarında dinîtasavvufi eserlerine nisbetle vezin yönünden daha itinalı davranmışlardır.

Tasavvufî şiirde aruzla yazılan şiirlerde en çok bahr-ı remel'den Fẩilâtün/ Fâ’ilâtün/ Fâ’ilâtün/ Fâ’ilün, Fâ'ilâtün/ Fâ'ilâtün/ Fâ'ilün, Fe'ilâtün/ Fe'ilâtün/ Fe'ilâtün/ Fe'ilün, Fe'ilâtün/ Fe'ilâtün/ Fe'ilün

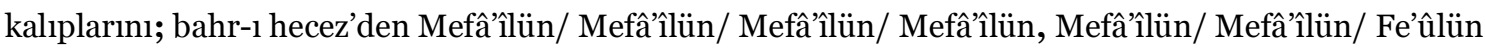
kalıpları; bahr-ı recez'den Müstefilün/ Müstefilün/ Müstefilün/ Müstef'ilün kalıbı çokça kullanılmıştır. Bu kalıplar klasik şiirimizde de çokça tercih edilen kalıplardır. Heceyle yazılan şiirlerde ise $8+8=16^{\prime} l 1,7+7=14^{\prime} l u ̈, 6+5=11^{\prime} l i$ hece ölçüleri çokça tercih edilmiştir. 4 müstef'ilün ve 4 mefầilün kalıbıyla yazılan şiirler 8'li hece ölçüsüyle, Fâ’ilâtün/ Fâ’ilâtün/ Fâ’ilün ve Fe'ilâtün/ Fe'ilâtün/ Fe’ilün kalıbıyla yazılan şiirler 11'li hece ölçüsüyle uyumludur. Bu vezinlerin tercihinde Türk halkının şiir zevkinin etkili olduğunu söylemek mümkündür. Bu tür kalıplarla yazılıp aruz kusurlarının fazlaca olduğu şiirlerin aruzla mı yoksa heceyle mi yazıldığı konusunda farklı yorumlar ortaya çımıştır.

Sûfî şairlerin şekilden ziyade manaya önem vermeleri, şiirlerinde aruz kusurlarını göz ardı etmelerine yol açmıştır. Hemen her şiirde çok sayıda imale kusuruna rastlamak mümkündür. İmaleye göre daha ağır bir kusur sayılan zihaf ise çok nadir görülen bir aruz kusurudur. Medli hecelerin kullanımında da tam bir birlik yoktur. Bazı şairler medli heceyi doğru kullanırken bazı şairlerin medli heceyi bir hece saydığı, bazı şairlerinse "nun" ile bittiği için tek hece sayılması gereken uzun heceleri bir buçuk hece saydıkları görülmüştür.

Sûfî şairin temel gayesi tasannu yapmaktan ziyade hakikat olmuştur. Bu bakış açısı sûfî şairin poetikasını da belirlemiştir. Ne söylendiği nasıl söylediğinden daha ön planda olan bir şiirde şeklin ve edebî sanatların göz ardı edilebileceği gerçeğine bağlı olarak tasavvufi şiirde vezin, kafiye, birim gibi konular klasik şiirdeki kadar bağlayıcı olmamıştır. Dünyevi kayıtlardan azade bir ruh dünyasına sahip sûfî şairin bu hâlini şiirine de taşıması kaçınılmaz olmuştur. Bununla birlikte tasannu yapmak için yazılmış şiirlerden geri kalmayacak söyleyiş güzelliğine, inceliğine; ustalıkla uygulanmış vezin ve kafiyeye sahip tasavvufi şiirler de yok değildir.

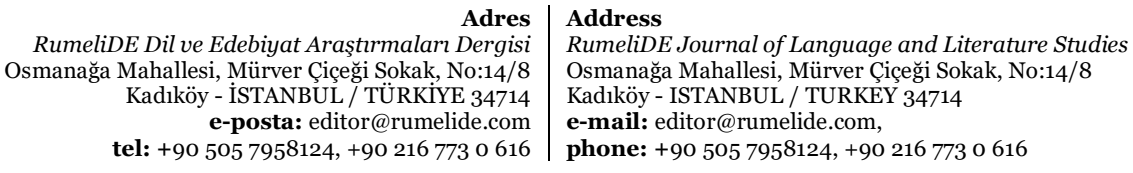




\section{Kaynakça}

Ayvazoğlu, B. (1993). Aşk Estetiği. İstanbul: Ötüken Neşriyat.

Behar, C. (1998). Aşk Olmayınca Meşk Olmaz: Geleneksel Osmanl/Türk Müziğinde Öğretim ve Intikal. İstanbul: YKY.

Beyatlı, Y. K. (1971). Edebiyata Dair, İstanbul: Yahya Kemâl Enstitüsü.

Ceylan, Ö. (2010). Böyle Buyurdu Sûfi. İstanbul: Kapı Yayınları.

Doğramacı, B. (1977). Kemâli Divanı’ndan Aşk Sızıntıları. İstanbul: Divan Matbaacılık.

Erzurûmî, İ. H. (H. 1263). Dîvân-ı İbrâhîm Hakkı Erzurûmî. https://acikerisim.tbmm.gov.tr/xmlui/handle/11543/1143 linkinden 07.09.2021 tarihinde erişilmiş̧tir.

Farsakoğlu, A. (2010). Hâce Muhammed Lutfì Efendi'nin Şïrlerinde Dinî ve Tasavvufí Unsurlar. (Doktora tezi). Erzurum: Atatürk Üniversitesi Sosyal Bilimler Enstitüsü.

Güzel, A. (2004). Kaygusuz Abdal, 2. b. Ankara: Akçă̆ Yayınları.

Güzel, A. (2021). Şehzâde Alâ̂ddin Gaybî Kaygusuz Abdâl Külliyatı: (Hayatı-Eserleri-Metin- SözlükKaynaklar), Ankara: Türk Dil Kurumu Yayınları.

İpekten, H. (1994). Eski Türk Edebiyat Nazım Şekilleri ve Aruz. 1.b. İstanbul: Dergâh.

İsen, M. (1990). Usûlî Dîvânı, Ankara: Akçağ Yayınları.

İsen, M. (2020). Usûli Dîvânı, 1. b. İstanbul: Türkiye Yazma Eserler Kurumu Başkanlığı Yayınları.

İyiyol, F. (2013). Anonim Olmayan Mâniler: Dinî-Tasavvufî Türk Halk Edebiyatı Örnekleri, Motif Akademi Halkbilimi Dergisi, 6 (12), 261-276.

Kemikli, B. (2003). Oğlanlar Şeyhi İbrahim Müfid ü Muhtasar. İstanbul: Kitabevi.

Kemikli, B. (2007). Şiir ve Hikmet. İstanbul: Kitabevi.

Kemikli, B. (2015). Bir Hak Âşı̆̆ı Osman Kemâlı̂ Efendi, Erzurum: Atatürk Üniversitesi Yayınevi.

Kemikli, B. (2017). Sun’ullah-ı Gaybî Dîvânı. İstanbul: H Yayınları.

Kemikli, B. (2018). Türk İslâm Edebiyatı Giriş. Bursa: Emin Yayınları.

Kılıç, M. E. (2014). Sûfi ve Şïr. İstanbul: İnsan Yayınları.

Kocatürk, V. M. (1970). Türk Edebiyatı Tarihi. Ankara: Edebiyat Yayınları.

Köksal, F. (2009). Metin Neşrinde Vezinle İlgili Problemler, Bazı Tespit ve Teklifler, Divan Edebiyatı Araştırmaları Dergisi, 3, 63-86.

Lutfî ,H. M. (2006). Hülâsatü'l-Hakâyık ve Mektûbât-ı Hâce Muhammed Lutfí, İstanbul: Damla Yayınları.

Okcu, N. (2011). Şeyh Gâlib Dîvânı. Ankara: TDV Yayınları.

Özsoy, B. S. (2011). Başlangıcından Günümüze Örnekleriyle Türk Şïiri. Ankara: Akçă̆ Yayınları.

Süer, F. R. (2017). Şemseddîn-i Sivâsî Dîvânı. İstanbul: H Yayınları.

Tanrıkorur, Ç. (1995). Türk Musikisinde Usul-Vezin Münasebeti, Ekrem Hakkı Ayverdi Hatıra Kitabı. İstanbul: Fetih Cemiyeti Yayınları.

Tatcı, M. (2015). Niyâzî̀-i Mısrî Halvetî Dîvân-ı İlâhiyât. İstanbul: H Yayınları.

Tatcı, M. (1990). Yûnus Emre Dîvânı İnceleme. Ankara: Kültür Bakanlığı Yayınları.

Tatcı, M. (2008). Aşk Bir Güneşe Benzer. İstanbul: H Yayınları.

Tenik, A. (2017). Tasavvufî Şiir Poetikası . İlahiyat Tetkikleri Dergisi , (48), 141-160.

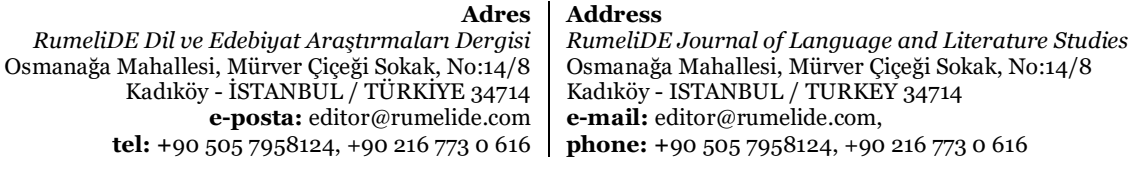


Ünal, M. \& Çalışkan, N. (2014). Bir Sûfî Şairin Şiiri: Haşim Baba Örneği . Süleyman Demirel Üniversitesi Sosyal Bilimler Enstitüsü Dergisi, (20), 231-240.

Ünver, İ. (1987). “Kemâl-i Ümmî”, Bolu İli Halk Edebiyatı Sempozyumu (Bildiriler Kitabı). Bolu: Bolu Kalkınma ve Tanıtma Vakfı Yayınları.

Yavuzer, H. (1997). Kemal Ümmi Divanı İnceleme-Metin. (Doktora tezi). Ankara: Gazi Üniversitesi Sosyal Bilimler Enstitüsü.

Yavuzer, H. (2008). Kemal Ümmî Dîvânı İnceleme-Metin. Bolu: Bamer Yayınları.

Yurtsever, M. (1990). Ísmail Hakkı Divanı: İnceleme - Metin. (Doktora tezi). Bursa: Uludağ Üniversitesi Sosyal Bilimler Enstitüsü.

RumeliDE Dil ve Edebiyat Araştırmaları Dergisi Osmanağa Mahallesi, Mürver Çiçeği Sokak, No:14/8 Kadıköy - İSTANBUL / TÜRKIYE 34714 e-posta: editor@rumelide.com tel: +90 $5057958124,+902167730616$
Address

RumeliDE Journal of Language and Literature Studies Osmanağa Mahallesi, Mürver Çiçeği Sokak, No:14/8

Kadıköy - ISTANBUL / TURKEY 34714

e-mail: editor@rumelide.com,

phone: +90 505 7958124, +90 2167730616 